\title{
POLINOMIÁLIS OPTIMALIZÁLÁSI FELADATOK ÉS RELAXÁCIÓIK
}

\author{
PAPP DÁVID
}

\begin{abstract}
Polinomok zárt félalgebrai halmazok feletti szélsőértékeinek meghatározása nehéz, de számtalan (matematikai és egyéb) alkalmazásokkal bíró feladat. Ebben a dolgozatban rövid áttekintést adunk a feladat algebrai hátteréről és megoldásának numerikus módszereiről. A polinomiális optimalizálás NP-nehéz, ezért hatékonyan megoldható relaxációk és közelítő módszerek keresése népszerü kutatási terület. Két megközelítést ismertetünk: az első a négyzetösszeggé alakítás módszere, ami Schmüdgen, Putinar, és mások Positivstellensatzként ismert tételein alapul, a másik a nemnegatív körpolinomok módszere, ami súlyozott számtani-mértani közepek közötti egyenlőtlenségeket használva korlátozza az optimalizálandó polinomot. A két módszer leírása után azt is vázoljuk, hogyan oldhatjuk meg a közelítő feladatokat a szemidefinit programozás és a nemszimmetrikus kúpprogramozás belsőpontos módszereivel.
\end{abstract}

\section{Bevezetés}

A polinomiális optimalizálás alapfeladata a következő: határozzuk meg egy adott, $n$ változós, $d$-edfokú, valós együtthatós $f$ polinom legkisebb értékét egy polinomiális egyenlőtlenségekkel megadott

$$
S:=\left\{\mathbf{x} \in \mathbb{R}^{n} \mid g_{i}(\mathbf{x}) \geq 0 \quad i=1, \ldots, m\right\}
$$

zárt félalgebrai halmaz felett, pontosabban az

$$
\inf \{f(\mathbf{x}) \mid \mathbf{x} \in S\}
$$

értéket, illetve a feladat egy optimumhelyét, amennyiben $f$ felveszi az infimumát (Ez utóbbi automatikusan teljesül, ha $S$ korlátos.).

A polinomiális optimalizálásnak (illetve a szorosan kapcsolódó kérdésnek, hogy egy polinomnak van-e zérushelye egy adott félalgebrai halmazon) számtalan alkalmazása ismert, mind a matematikai tudományokon belül, mind azon kívül, ezek közül csak néhányat említünk meg. Diszkrét geometriai feladatok felírhatók polinomiális optimalizálási feladatként [5, 6]. Statisztikai kísérlettervezésben és érzékelők optimális elhelyezésének feladatában az optimális konfigurációk leírhatók 
nemnegatív polinomok gyökeinek halmazaként (pl. [33]). Szabályozástechnikában és dinamikus rendszerek tervezésében a félegyenesen és magasabb dimenziós féltereken nemnegatív polinomok fontos szerepe révén alkalmazható a polinomiális optimalizálás [16, 4, 2, 24, 49]. A pozitív (vagy nemnegatív) gyökök létezése a reakciókinetikában is fontos kérdés [52, 7. fej.], [9], ez is átfogalmazható polinomiális optimalizálási feladatként (ahol $S$ az első ortáns).

A polinomiális optimalizálás NP-nehéz már abban a speciális esetben is, ha $m=0\left(\right.$ azaz $\left.S=\mathbb{R}^{n}\right)$ és $d=4$, illetve abban az esetben is, ha $S=[0,1]^{n}$ és $d=2$; a [10] cikk számos klasszikus NP-nehéz kombinatorikus optimalizálási feladatot visszavezet az utóbbi problémára. A polinomiális optimalizálás algebrai és numerikus módszereiről számos nagyobb lélegzetű összefoglaló cikk és monográfia készült, például [27], [29], és [7]. Ennek a cikknek kettős célja van: egyrészt egy rövid magyar nyelvü összefoglalást ad a polinomális optimalizálás legfontosabb eszközeiről, másrészt kiemel néhány közelmúltbeli eredményt és aktív kutatási irányt, amik az említett „klasszikus” forrásokban nem találhatók meg.

A polinomiális optimalizálás feladata szorosan kapcsolódik a nemnegatív polinomok karakterizációjának feladatához. Jelölje $\mathcal{P}_{d}^{S}$ az $S$ halmazon nemnegatív $d$-edfokú polinomok halmazát, ekkor a (2) optimalizálási feladat így is írható:

$$
\sup \left\{c \mid f-c \in \mathcal{P}_{d}^{S}\right\} .
$$

Érdemes megemlítenünk, hogy bár a (2) feladat általában nem konvex optimalizálási feladat (hiszen általános esetben sem az $f$ célfüggvény, sem pedig a megengedett megoldások $S$ halmaza nem konvex), a (3) formában írva azonban már konvex, hiszen a célfüggvény lineáris, és a $\mathcal{P}_{d}^{S}$ halmaz is konvex minden $d$-re és $S$-re, függetlenül attól, hogy $S$ konvex-e. A „trükk” az, hogy a (2) és (3) feladatok különböző terekben optimalizálnak (az előbbi feladat változói nem jelennek meg az utóbbiban). A konvex alak természetesen nem jelenti azt, hogy a feladat egyszerübben megoldható, a (3) feladat is NP-nehéz, de a konvexitás egyéb következményei (pl. optimalitási feltételek, a lokális minimumok globális minimum volta) fontosak és felhasználhatók algoritmusok tervezésben.

A (2) feladat nehézsége abból is levezethető, hogy már annak eldöntése is NPnehéz, hogy egy polinom nemnegatív-e az $S$ halmaz felett. Másodfokú polinomok esetén, ha $S=\mathbb{R}_{+}^{n}$, a kérdés ekvivalens annak eldöntésével, hogy egy adott valós szimmetrikus mátrix teljesen pozítiv-e [30]. A teljesen pozitív kúpba tartozás kérdésének erős NP-teljességét a közelmúltban bizonyították precízen [14].

Mindezekből következik, hogy a polinomiális optimalizálás feladatára, a legegyszerübb speciális esetektől eltekintve, nem várható hatékony (polinomiális futásidejü) algoritmus. A (2) feladat megoldását célzó numerikus módszerek stratégiája ezért a következő: a feladat (3) alakjában a nehezen kezelhető $\mathcal{P}_{d}^{S}$ kúpot egy olyan közelítő kúpra cseréljük, amelyre a kúpba tartozás kérdése polinomidőben eldönthető. A közelítés pontossága és a futásidő között kompromisszumot kell kötnünk: a módszerek általában nem egy közelítő kúppal dolgoznak, hanem közelítő kúpok 
egy $K_{1} \subseteq K_{2} \subseteq \cdots \subseteq \mathcal{P}_{d}^{S}$ sorozatával, amelyre $\cup_{i=1}^{\infty} K_{i}=\mathcal{P}_{d}^{S}$. Fontos, hogy a $K_{i}$ kúp belülről közelítse a $\mathcal{P}_{d}^{S}$ kúpot: így a $\sup \left\{c \mid f-c \in K_{i}\right\}$ feladat minden megengedett megoldása alsó korlátot ad a (2) feladat megoldására, továbbá az $f-c$ polinom $K_{i}$-beli tagsága egy polinomidőben ellenőrizhető tanúsítványa a $c \leq \inf \{f(x) \mid x \in S\}$ egyenlőtlenségnek.

A következő két szakasz a $\mathcal{P}_{d}^{S}$-t belülről közelítő kúpok két családját mutatja be részletesebben.

\section{Négyzetösszeggé alakítható (SOS) polinomok és szemidefinit optimalizálás}

Egy valós együtthatós p polinom négyzetösszeggé alakitható (angolul sum-ofsquares, röviden $S O S$ ), ha előáll valós együtthatós polinomok négyzetösszegeként: $p=\sum_{i=1}^{j} q_{i}^{2}$. Az $n$ változós $2 d$-edfokú négyzetösszeggé alakítható polinomok halmazát jelölje $\Sigma_{n, 2 d}$. Nyilvánvaló, hogy az SOS tulajdonság a nemnegativitás elégséges feltétele: $\Sigma_{n, 2 d} \subseteq \mathcal{P}_{2 d}^{\mathbb{R}^{n}}$. (A feltétel nem szükséges, ld. a 2.2. tételt.) $\mathrm{Az}$ is könnyen belátható, hogy $\Sigma_{n, 2 d}$ egy zárt konvex kúp, amelyre $\operatorname{dim} \operatorname{span}\left(\Sigma_{n, 2 d}\right)=\operatorname{dim} \operatorname{span}\left(\mathcal{P}_{2 d}^{\mathbb{R}^{n}}\right)=\left(\begin{array}{c}n+2 d \\ 2 d\end{array}\right)$.

A nemnegativitás és négyzetösszeggé alakíthatóság kapcsolatának vizsgálata már a XIX. században megkezdődött: polinomok helyett racionális törtfüggvényekre a két tulajdonság ekvivalens [3], ez Hilbert 17-ik problémája [21], ám ebből még nem következik, hogy a négyzetösszeggé alakítás könnyen megoldható. Újabb eredmény, hogy az SOS polinomok felismerése polinomidőben visszavezethető egy szemidefinit optimalizálási feladatra [46, 31]. A szemidefinit optimalizálás feladatának pontos definíciójához szükségünk lesz az alábbi jelölésekre.

Legyen $\mathbb{S}^{k}$ a $k \times k$ méretü valós szimmetrikus mátrixok halmaza és $\mathbb{S}_{+}^{k}$ a pozitív szemidefinit $k \times k$ mátrixok halmaza. Használjuk továbbá az $\mathbf{A} \succcurlyeq \mathbf{B}$ egyenlőtlenséget annak jelölésére, hogy az $\mathbf{A}-\mathbf{B}$ mátrix pozitív szemidefinit.

2.1. Definíció. A $H \subseteq \mathbb{R}^{n}$ halmaz szemidefiniten reprezentálható, ha valamilyen $k \geq 1$ és $\ell \geq 0$ egész számra léteznek olyan $A: \mathbb{R}^{n} \rightarrow \mathbb{S}^{k}$ és $C: \mathbb{R}^{\ell} \rightarrow \mathbb{S}^{k}$ affin (elsőfokú, nem feltétlenül homogén) függvények, amelyekkel $H$ a következőképpen írható:

$$
H=\left\{\mathbf{x} \in \mathbb{R}^{n} \mid \exists \mathbf{u} \in \mathbb{R}^{\ell}: A(\mathbf{x})+C(\mathbf{u}) \succcurlyeq \mathbf{0}\right\} .
$$

A definíció közvetlen következménye, hogy minden szemidefiniten reprezentálható halmaz konvex. Egy sokat vizsgált, algebrai geometriai szemszögböl különösen érdekes speciális eset az $\mathbf{u}$ "segédváltozók" nélküli $\ell=0$ eset: a $H$ halmaz egy spektraéder, ha felírható (4) alakban és $\ell=0$ [55]. Ha továbbá $A(\mathbf{x})$ értéke diagonális mátrix minden $\mathbf{x}$-re, akkor $H$ egy konvex poliéder (és fordítva, minden konvex poliéder szemidefiniten reprezentálható ilyen módon). 
Az előbbiek segítségével azt mondjuk, hogy egy optimalizálási probléma egy szemidefinit optimalizálási feladat, ha felírható

$$
\inf \left\{\mathbf{c}^{\mathrm{T}} \mathbf{x} \mid \mathbf{x} \in H\right\}
$$

alakban, ahol $\mathbf{c} \in \mathbb{R}^{n}$ és $H$ egy szemidefiniten reprezentálható halmaz.

Szemidefinit optimalizálási feladatok a lineáris programozásra emlékeztető módon standard alakra hozhatók [53, 54]. A standard alak egyik szokásos (primál) formája

$$
\inf \left\{\mathbf{C} \bullet \mathbf{X} \mid \mathbf{A}_{i} \bullet \mathbf{X}=b_{i}, i=1, \ldots, m ; \mathbf{X} \succcurlyeq \mathbf{0}\right\},
$$

ahol • jelöli a mátrixok skaláris (Frobenius) szorzatát, az $\mathbf{A}_{i} \in \mathbb{S}^{k}$ mátrixok, a $\mathbf{b} \in \mathbb{R}^{m}$ vektor és a $\mathbf{C} \in \mathbb{S}^{k}$ mátrix adottak, és $\mathbf{X}$ az optimalizálási változó. Ekkor a duális feladat így írható:

$$
\sup \left\{\mathbf{b}^{\mathrm{T}} \mathbf{y} \mid \mathbf{C}-\sum_{i=1}^{m} \mathbf{A}_{i} y_{i} \succcurlyeq \mathbf{0}\right\} .
$$

Szemidefinit optimalizálási feladatok polinomiális futásidővel megoldhatók, ha az $\mathbf{A}_{i}$ és $\mathbf{C}$ együtthatómátrixok és a $\mathbf{b}$ vektor egészek, és a bemenet méretét kellő körültekintéssel definiáljuk [17, 41]. Ezt nem részletezzük, de annyit fontos megjegyeznünk, hogy (a lineáris programozással ellentétben!) csupán az $\mathbf{A}_{1}, \ldots, \mathbf{A}_{m}$, b és $\mathbf{C}$ méretében polinomiális futásidőben a szemidefinit optimalizálási feladatok általában nem oldhatók meg.

A gyakorlatban belsőpontos algoritmusokkal az (5-6) feladatok meglehetősen nagy méretü példányai, ahol $k$ és $m$ tízezres nagyságrendüek, viszonylag könnyen megoldhatók. (2.2. szakasz.)

A polinomiális optimalizálás egyik alapvető eredménye, hogy (minden $(n, d)$ párra) a $\Sigma_{n, 2 d}$ kúp és duális kúpja szemidefiniten reprezentálhatók [31, 38, 26].

2.1. TÉTEL. ([31]) Legyen $L=\left(\begin{array}{c}n+d \\ d\end{array}\right)$ és $U=\left(\begin{array}{c}n+2 d \\ 2 d\end{array}\right)$, továbbá legyen $\mathbf{p}=$ $\left(p_{1}, \ldots, p_{L}\right)$ az $n$ változós $d$-edfokú polinomok egy tetszóleges rendezett bázisa, és legyen $\mathbf{q}=\left(q_{1}, \ldots, q_{U}\right)$ az $n$ változós $2 d$-edfokú polinomok egy tetszöleges rendezett bázisa. Jelölje $\Lambda$ azt az (egyértelmüen meghatározott) lineáris $\mathbb{R}^{U} \rightarrow \mathbb{S}^{L}$ leképezést, amelyre $\Lambda(\mathbf{q})=\mathbf{p p}^{\mathrm{T}}$, míg $\Lambda^{*}$ ennek az adjungáltját. Ekkor $\mathbf{x} \in \Sigma_{n, 2 d}$ akkor és csak akkor, ha létezik olyan $\mathbf{X} \in \mathbb{S}_{+}^{L}$ mátrix amelyre

$$
\mathbf{x}=\Lambda^{*}(\mathbf{X})
$$

Ennek következményeképpen a $\Sigma_{n, 2 d}$ kúp duális kúpja is szemidefiniten reprezentálható (sőt, spektraéder):

$$
\Sigma_{n, 2 d}^{*}=\left\{\mathbf{s} \in \mathbb{R}^{U} \mid \Lambda(\mathbf{s}) \succcurlyeq \mathbf{0}\right\} .
$$


2.1. Példa. Az algebra alaptételének egyszerü következménye, hogy egy egyváltozós valós együtthatós polinom akkor és csak akkor nemnegatív a teljes számegyenesen, ha SOS [39, 44. feladat]. A 2.1. Tételt alkalmazva azt kapjuk, hogy a $p(t)=\sum_{k=0}^{2 d} p_{k} t^{k}$ egyenlőséggel definiált $p$ polinom akkor és csak akkor nemnegatív a teljes számegyenesen, ha létezik olyan valós pozitív szemidefinit $\mathbf{X}=\left(x_{i j}\right)_{i, j=0}^{d}$ mátrix, amelyre

$$
p_{k}=\sum_{i+j=k} x_{i j}, \quad k=0, \ldots, 2 d .
$$

(Ez az X mátrix általában nem egyértelmü.) A duális $\Sigma_{1,2 d}^{*}$ kúp pedig az olyan $\mathbf{s}=\left(s_{0}, \ldots, s_{2 d}\right) \in \mathbb{R}^{2 d+1}$ vektorok kúpja, amelyekre az

$$
\left(\begin{array}{ccccc}
s_{0} & s_{1} & s_{2} & \cdots & s_{d} \\
s_{1} & s_{2} & & & s_{d+1} \\
s_{2} & & . \cdot & & \\
\vdots & & & & \vdots \\
s_{d} & s_{d+1} & \cdots & & s_{2 d}
\end{array}\right)
$$

Hankel-mátrix pozitív szemidefinit.

\subsection{A nemnegatív és négyzetösszeggé alakítható polinomok kapcsolata}

Mikor azonos a négyzetösszeggé alakítható és a nemnegatív polinomok halmaza? Erre a kérdésre Hilbert alábbi tétele ad választ:

2.2. TÉTEL. ([20]) $\Sigma_{n, 2 d}=\mathcal{P}_{n, 2 d}$ akkor és csak akkor, ha $n=1$ vagy $2 d=2$ $\operatorname{vagy}(n, 2 d)=(2,4)$.

Amint említettük, az $n=1$ eset az algebra alaptételéből egyszerüen levezethető. A másodfokú (többváltozós) esetben az állítás annak az átfogalmazása, hogy $\mathbf{A} \succcurlyeq \mathbf{0}$ akkor és csak akkor, ha $\mathbf{A}=\mathbf{B B}^{\mathrm{T}}$ valamilyen $\mathbf{B}$ mátrixra. A kétváltozós negyedfokú eset lényegesen bonyolultabb, ezért nem részletezzük. A többi esetre egyszerű ellenpéldák konstruálhatók: a kétváltozós, hatodfokú Motzkin-polinomot az

$$
m(x, y)=1-3 x^{2} y^{2}+x^{4} y^{2}+x^{2} y^{4}
$$

egyenlőséggel definiáljuk. Ez a polinom mindenhol nemnegatív, ezt a számtani és mértani közép közötti egyenlőtlenséggel bizonyíthatjuk. Viszont elemi módszerekkel (a szemidefinit optimalizálási feladat vizsgálata nélkül) is belátható, hogy $m$ nem alakítható négyzetösszeggé. Hasonlóan, az $(n, 2 d)=(3,4)$ esetben a

$$
c(x, y, z)=1-4 x y z+x^{2} y^{2}+y^{2} z^{2}+z^{2} x^{2}
$$

egyenlőséggel megadott háromváltozós, negyedfokú polinom (a Choi-Lampolinom) egy mindenhol nemnegatív, ám négyzetösszeggé nem alakítható polinom. 
A 2.2. Tétel nem biztató, azonban Artin [3] előbb említett eredménye szerint minden nemnegatív polinom felírható racionális törtfüggvények négyzetösszegeként. Ez motiválja a következő stratégiát $\inf \left\{f(\mathbf{x}) \mid \mathbf{x} \in \mathbb{R}^{n}\right\}$ becslésére. Rögzítsünk egy $c_{0}$ célszámot, amelyre szeretnénk belátni, hogy $c_{0} \leq \inf \left\{f(\mathbf{x}) \mid \mathbf{x} \in \mathbb{R}^{n}\right\}$ (az optimális értéket $c_{0}$-ra alkalmazott bináris kereséssel közelíthetjük), majd válasszunk egy $r$ fokszámot, és keressünk olyan $s_{1} \in \Sigma_{n, r}$ és $s_{2} \in \Sigma_{n, 2 d+r}$ polinomokat, amelyekre

$$
s_{1}\left(f-c_{0}\right)=s_{2} .
$$

Az előbbiek alapján a (9) feladat megoldhatósága szemidefinit optimalizálással eldönthető. Ha találunk megoldást, akkor $f \geq c_{0}$ mindenhol. Ha nem találunk megoldást, akkor az $r$ fokszámot növelve próbálkozhatunk újra. Artin tétele szerint minden $f$ és $c_{0}$ értékre vagy létezik olyan $\mathbf{x} \in \mathbb{R}^{n}$ amelyre $f(\mathbf{x})<c_{0}$ vagy létezik olyan $r$ fokszám, amelyre (9) megoldható. A módszer praktikussága kétségbe vonható, mert $r$ értékére nem adható alacsony korlát. Ez jelenleg is aktív kutatási terület; Lombardi, Perrucci és Roy közelmúltbeli eredménye még nem sok jóval kecsegtet:

2.3. TÉtel. ([28]) Ha $f \geq c_{0}$, akkor (9) megoldható valamilyen $r \leq 2^{2^{2^{d^{4^{n}}}}}-r e$.

Az (1) alakban megadott félalgebrai $S$ halmazok felett nemnegatív polinomok esete elméletileg hasonlóan kezelhető, és ha a megengedett megoldások halmaza korlátos, akkor a szükséges fokszámok is lényegesen alacsonyabbak.

Nyilvánvaló, hogy az (1) formában megadott $S$ halmazon minden olyan $p$ polinom nemnegatív, amelyre $p=g_{i} s$ valamilyen $s$ SOS polinommal. Általánosabban, ha $p=\sum_{I \subseteq\{1, \ldots, m\}}\left(\prod_{i \in I} g_{i}\right) s_{I}$ és minden $s_{I}$ négyzetösszeggé alakítható, akkor $p$ nemnegatív. Az ilyen formában írható polinomokat súlyozott négyzetösszeggé alakitható (weighted-sum-of-squares) polinomoknak nevezzük. Az állítás (részleges) megfordítása Schmüdgen tétele:

2.4. TÉTEL. ([43]) Legyen $S$ az (1) egyenletben megadott halmaz, és tegyük fel hogy $S$ kompakt. Ekkor minden az $S$ halmazon (szigorúan) pozitív p polinom felírható

$$
p=\sum_{I \subseteq\{1, \ldots, m\}}\left(\prod_{i \in I} g_{i}\right) s_{I}
$$

alakban, ahol az $s_{I}, I \subseteq\{1, \ldots, m\}$ polinomok négyzetösszeggé alakíthatók.

Putinar eredménye az állítás erősebb formája:

2.5. TÉTEL. ([40]) Jelölje $r$ az $\left(x_{1}, \ldots, x_{n}\right) \mapsto \sum_{i=1}^{n} x_{i}^{2}$ polinomot, és tegyük fel, hogy $C-r=\sum_{i=1}^{m} g_{i} q_{i}$ valamilyen négyzetösszeggé alakítható $q_{1}, \ldots, q_{m}$ polinomokra és $C$ konstansra. Ekkor minden az $S$ halmazon (szigorúan) pozitív $p$ 
polinom felírható

$$
p=s_{0}+\sum_{i=1}^{m} g_{i} s_{i}
$$

alakban, ahol az $s_{0}, \ldots, s_{m}$ polinomok négyzetösszeggé alakíthatók.

Praktikus szempontból Putinar 2.5. Tétele a hasznosabb: a 2.1. Tétel értelmében minden SOS polinom reprezentálásához egy külön pozitív szemidefinit mátrixra van szükség, tehát a (10) reprezentációból konstruálható szemidefinit optimalizálási feladatnak $2^{m}$ mátrix változója van, míg a (11) reprezentációt használva csak $m+1$ szemidefinit mátrixra van szükség. Putinar tételének szigorúbb feltétele az általánosság megszorítása nélkül feltehető: ha $S$ korlátos, akkor $S$ reprezentációjához mindig hozzáadható a (redundáns) $g_{m+1}(\mathbf{x}):=C-r(\mathbf{x}) \geq 0$ egyenlötlenség egy kellöen nagy $C$ konstanssal; ezzel viszont $C-r=g_{m+1}$ triviálisan kielégíti a Putinar-tétel feltételét.

Megjegyzés. Schmüdgen és Putinar tételeire (és más hasonló, a félalgebrai halmazok felett nemnegatív polinomokat karakterizáló tételekre) a szakirodalom kollektíven Positivstellensatz tételekként hivatkozik, Hilbert nullahelytételéhez (Nullstellensatz) való hasonlatosságuk miatt. Az SOS polinomok fokszámának növelésével kapható szemidefinit optimalizálási feladatok sorozatára pedig szemidefinit optimalizálási hierarchiaként hivatkozik a szakirodalom.

Schmüdgen és Putinar tétele esetében is fontos kérdés, hogy milyen felső korlát adható a tételekben szereplő $s_{i}$ SOS polinomok fokszámára. A Schmüdgenhierarchia esetében Stengle [47], valamint Schweighofer és Nie [44] vizsgálta a fokszámok és a becslés hibájának kapcsolatát. A Putinar-hierarchia esetére hasonló eredmények a [32] cikkben olvashatók. Ezek lényegesen alacsonyabb korlátok, mint a 2.3. Tételbeli fokszámkorlát.

Az alkalmazásokban leggyakrabban felmerülő félalgebrai halmazok esetében általánosabb és egyszerübben bizonyítható Positivstellensatzok adhatók: a nemnegatív ortáns esetére Pólya [19, 57. old.], konvex politópok esetére Handelman [18] eredményét fontos megemlítenünk. Ebben a két esetben a szemidefinit optimalizálás teljesen meg is kerülhető, helyettük már lineáris optimalizálási feladatok sorozatával is adhatunk a polinom minimumértékéhez konvergáló alsó korlátot. A szükséges fokszámok is alacsonyabbak $[12,13]$.

További hivatkozások. Az SOS polinomok és szemidefinit optimalizálás kapcsolatának vizsgálata Parrilo [38] és Lasserre [26] munkáiból eredeztethető. A részletek iránt érdeklődő olvasónak Laurent összefoglaló cikkét [27] ajánljuk. A polinomiális optimalizálást absztrakt algebrai szemszögből a [29] és [7] monográfiák mutatják be, míg az alapvető algoritmikus kérdések számítási bonyolultságát a [11] cikk taglalja részletesen. 


\subsection{Numerikus módszerek}

A szemidefinit optimalizálás numerikus módszereit részletesen tárgyalja az [57] és [41] könyv. A legnépszerübb és -hatékonyabb megoldóalgoritmusok belsőpontos algoritmusok, amik a lineáris optimalizálás belsőpontos módszereinek [23, 42, 50] természetes általánosításai. (A szimplex módszernek, a kombinatorikus struktúra hiányában, nincs analogonja a szemidefinit optimalizálásban.) Népszerű implementációk a nyílt forráskódú SeDuMi [48], SDPT3 [51] és CSDP [8], valamint a (nem ingyenes) MOSEK. A YALMIP és CVX Matlab csomagok segítenek a szemidefinit optimalizálási feladattá alakítható optimalizálási feladatok felismerésében, illetve leírásában.

Az SOS polinomok szemidefinit reprezentációnak fő hátránya a szemidefinit optimalizálási feladatok óriási mérete. A 2.1. Tétel értelmében egy $\left(\begin{array}{c}n+2 d \\ 2 d\end{array}\right)$-dimenziós $\Sigma_{n, 2 d}$-beli vektor leírásához egy $\left(\begin{array}{c}n+d \\ d\end{array}\right) \times\left(\begin{array}{c}n+d \\ d\end{array}\right)$ méretü szemidefinit mátrixra van szükség. Ha $n$ rögzített, akkor a szemidefinit mátrix elemeinek száma (a $d$ fokszám függvényében) a vektor dimenziójánál nagyságrendekkel nagyobb: például $n=1$ esetén az SOS polinom $(2 d+1)$-dimenziós, míg a polinomot reprezentáló szemidefinit mátrix $(d+1) \times(d+1)=\Theta\left(d^{2}\right)$ méretü. Ez akkor is gond, ha a megoldandó (2) optimalizálási feladatban minden polinom alacsony fokszámú, hiszen minden az előző fejezetben ismertetett hierarchia a négyzetösszeggé alakítható polinomok fokszámának növelésével javítja az optimumértékre adott alsó korlátot.

Nagyméretű polinomiális optimalizálási feladatok megoldása továbbra is aktív kutatási terület. Csak két ígéretes irányt említünk meg: a Positivstellensatzokból a 2.1. tétel segítségével felírt szemidefinit optimalizálási feladatokat azok leírása nélkül megoldhatjuk nemszimmetrikus kúpok feletti optimalizálási algoritmusokkal [36, 37]. Amennyiben még ez is túl költséges, akkor a négyzetösszeggé alakítható polinomokat tovább közelíthetjük egyszerübb kúpokkal, ha a hierarchiákban a szemidefinit mátrixokat például diagonálisan domináns mátrixokra cseréljük [1]. Ezzel kapcsolatban azonban fontos megemlítenünk, hogy Putinar és Schmüdgen Positivstellensatzai ezekkel a közelítésekkel már nem teljesülnek, tehát ez csupán egy heurisztika, nem egy elméletileg megalapozott módszer. Egyszerü ellenpéldákat C. Josz [25] cikkében találhatunk.

Gyakran felmerülő kérdés, hogy a hierarchiákban használt magas fokszámú polinomok nem vezetnek-e numerikus nehézségekhez. A válasz elsősorban attól függ milyen bázisban reprezentáljuk az SOS polinomokat. A szokásos monomiális bázis nagy körültekintést igényel, hiszen már a polinomok kiértékelése is numerikusan instabil. Kompakt $S$ halmazok felett értelmezett (súlyozott) SOS polinomok esetén a polinomokat Lagrange interpolációs bázisban reprezentálva a 2.1. Tételbeli szemidefinit optimalizálási feladat numerikusan problémamentes [34]. Ha $S=[a, b]^{n}$, akkor még egyszerübb és hatékonyabb a másodfajú Csebisev-polinomok bázisában reprezentálni a polinomokat [36]. 


\section{A számtani és mértani közép közötti egyenlötlenségen alapuló relaxációk}

A nemnegatív, de négyzetösszeggé nem alakítható polinomokra adott két klasszikus példánk (a Motzkin- és a Choi-Lam-polinom) nemnegativitása a számtani és mértani közepek közötti egyenlőtlenséggel egyszerüen bizonyítható. Természetes ötlet, hogy az SOS tulajdonság helyett (vagy mellett) használjuk ezt a nemnegativitás elégséges feltételeként. Az elméleti nehézség, hogy (a négyzetösszeggé alakíthatóság konvexitásával ellentétben) egyáltalán nem világos, hogy a „számtani-mértani közép egyenlötlenséggel bizonyíthatóan nemnegatív polinomok" halmaza konvex-e. A kulcseredmény az alábbi, számtalanszor újrafelfedezett, 3.1. Tétel; ehhez használjuk a következő jelöléseket: minden $\mathbf{x}=\left(x_{1}, \ldots, x_{n}\right) \in \mathbb{R}^{n}$ és $\boldsymbol{\alpha}=\left(\alpha_{1}, \ldots, \alpha_{n}\right) \in \mathbb{N}^{n}$ vektorra, $\mathbf{x}^{\boldsymbol{\alpha}}:=\prod_{i=1}^{n} x_{i}^{\alpha_{i}}$. A $p$ polinom tartóhalmazát jelölje $\operatorname{supp}(p)$. Azt mondjuk, hogy a $p$ polinom egy körpolinom (circuit polynomial), ha tartóhalmaza $\operatorname{supp}(p)=\left\{\boldsymbol{\alpha}_{1}, \ldots, \boldsymbol{\alpha}_{r}, \boldsymbol{\beta}\right\}$ alakban írható, ahol az $\left\{\boldsymbol{\alpha}_{1}, \ldots, \boldsymbol{\alpha}_{r}\right\}$ egy affin független halmaz ${ }^{1}$ és $\boldsymbol{\beta}$ az $\boldsymbol{\alpha}_{i}$ vektorok konvex burkának belső pontja, azaz létezik egy (egyértelmü) $\boldsymbol{\lambda} \in \mathbb{R}_{+}^{r}$ pozitív együtthatóvektor, amelyre $\boldsymbol{\beta}=\sum_{i=1}^{r} \lambda_{i} \boldsymbol{\alpha}_{i}$ és $\sum_{i=1}^{r} \lambda_{i}=1$. Ezt úgy is fogalmazhatjuk, hogy egy körpolinom tartóhalmaza egy olyan minimálisan affin összefüggő halmaz, amelynek egyik eleme a többi elem konvex burkában található.

3.1. Példa. A (8) egyenletben definiált Motzkin-polinom tartóhalmaza $\left\{\left(\begin{array}{l}0 \\ 0\end{array}\right),\left(\begin{array}{l}2 \\ 2\end{array}\right),\left(\begin{array}{l}4 \\ 2\end{array}\right),\left(\begin{array}{l}2 \\ 4\end{array}\right)\right\}$. Ez egy minimálisan affin összefüggő halmaz, továbbá $\left(\begin{array}{l}2 \\ 2\end{array}\right)=$ $\frac{1}{3}\left(\begin{array}{l}0 \\ 0\end{array}\right)+\frac{1}{3}\left(\begin{array}{l}2 \\ 4\end{array}\right)+\frac{1}{3}\left(\begin{array}{l}4 \\ 2\end{array}\right)$. Ezért a Motzkin-polinom egy körpolinom.

3.1. TÉTEL. ([22]) Legyen $p$ a $p(\mathbf{x})=\sum_{i=1}^{r} c_{\boldsymbol{\alpha}_{i}} \mathbf{x}^{\boldsymbol{\alpha}_{i}}+c_{\boldsymbol{\beta}} \mathbf{x}^{\boldsymbol{\beta}}$ egyenlöséggel definiált körpolinom, és legyen $\boldsymbol{\beta}=\sum_{i=1}^{r} \lambda_{i} \boldsymbol{\alpha}_{i}, \sum_{i=1}^{r} \lambda_{i}=1$ az egyértelmüen meghatározott $\lambda_{i}>0$ együtthatókkal. Ekkor $p$ nemnegatív $\mathbb{R}^{n}$ felett akkor és csak akkor, ha minden $i=1, \ldots, r$-re $\boldsymbol{\alpha}_{i} \in(2 \mathbb{N})^{n}$ és $c_{\boldsymbol{\alpha}_{i}} \geq 0$, valamint az alábbi két állítás közül legalább az egyik teljesül:

1. $\boldsymbol{\beta} \in(2 \mathbb{N})^{n}$ és $c_{\boldsymbol{\beta}} \geq 0$, vagy

2. $\left|c_{\boldsymbol{\beta}}\right| \leq \prod_{i=1}^{r}\left(\frac{c_{\boldsymbol{\alpha}_{i}}}{\lambda_{i}}\right)^{\lambda_{i}}$.

A második alternatíva elégségessége a $\lambda_{i}$ együtthatókkal súlyozott számtani és mértani közepek közötti egyenlőtlenségből adódik. A tétel következménye, hogy körpolinomok esetén a nemnegativitás mindig bizonyítható ezzel az egyenlőtlenséggel. Általános (nem kör-) polinomok esetére, az SOS polinomokhoz hasonlóan, bevezethetjük a nemnegatív körpolinomok összegévé alakitható polinomok halmazát, ezt az egyszerüség kedvéért az angol nyelvű szakirodalomban használt rövidítéssel SONC-vel jelöljük (sum of nonnegative circuit polynomials). Egy $n$-változós

\footnotetext{
${ }^{1} \mathrm{Az}\left\{\boldsymbol{\alpha}_{1}, \ldots, \boldsymbol{\alpha}_{r}\right\}$ halmaz affin függetlensége azt jelenti, hogy a $\left\{\left(\begin{array}{c}\boldsymbol{\alpha}_{1} \\ 1\end{array}\right), \ldots,\left(\begin{array}{c}\boldsymbol{\alpha}_{r} \\ 1\end{array}\right)\right\}$ halmaz elemei lineárisan függetlenek.
} 
polinom $S O N C$ polinom, ha felírható $\mathbb{R}^{n}$ felett nemnegatív körpolinomok összegeként.

Az SOS tulajdonsághoz hasonlóan a SONC tulajdonság is a nemnegativitás elégséges de nem szükséges feltétele: az egyváltozós $\mathbb{R} \ni x \mapsto(1-x)^{4}$ polinom például nemnegatív a számegyenesen, azonban nem SONC. (Ebből már az is látható, hogy az SOS és SONC polinomok kúpjai közül egyik sem tartalmazza a másikat.)

A definíciókból világos, hogy a SONC polinomok halmaza egy konvex kúp, ám ebből még nem következik automatikusan, hogy a SONC polinomok könnyen felismerhetők, illetve hogy egy adott SONC polinom nemnegatív körpolinomok összegeként való felírására hatékony algoritmus adható. Ahogy a négyzetösszeggé alakíthatóság a 2.1. Tétel révén eldönthető szemidefinit optimalizálással, a SONC tulajdonság a 3.1. Tétel segítségével a hatványkúpok feletti optimalizálásra vezethetö vissza.

3.1. Definíció. Tegyük fel, hogy $\boldsymbol{\lambda} \in \mathbb{R}_{+}^{r}$ és $\sum_{i=1}^{r} \lambda_{i}=1$. Ekkor a $\boldsymbol{\lambda}$ paraméterü hatványkúp a

$$
\mathcal{K}_{\boldsymbol{\lambda}}:=\left\{(\mathbf{v}, z) \in \mathbb{R}_{+}^{r} \times \mathbb{R}|| z \mid \leq \mathbf{v}^{\boldsymbol{\lambda}}\right\}
$$

halmaz.

A $\mathcal{K}_{\boldsymbol{\lambda}}$ kúp egy konvex, zárt, $(r+1)$-dimenziós konvex kúp, amelynek duálisa (a skaláris szorzásra nézve) a

$$
\mathcal{K}_{\boldsymbol{\lambda}}^{*}:=\left\{(\mathbf{v}, z) \in \mathbb{R}_{+}^{r} \times \mathbb{R}|| z \mid \leq \prod_{i=1}^{r}\left(\frac{v_{i}}{\lambda_{i}}\right)^{\lambda_{i}}\right\}
$$

kúp. Ezzel a jelöléssel a 3.1. tétel második alternatívája egy egyszerü (konvex) kúpfeltételre cserélhető [35]:

$$
\left|c_{\boldsymbol{\beta}}\right| \leq \prod_{i=1}^{r}\left(\frac{c_{\boldsymbol{\alpha}_{i}}}{\lambda_{i}}\right)^{\lambda_{i}} \Longleftrightarrow\left(\left(c_{\boldsymbol{\alpha}_{1}}, \ldots, c_{\boldsymbol{\alpha}_{r}}\right), c_{\boldsymbol{\beta}}\right) \in \mathcal{K}_{\boldsymbol{\lambda}}^{*} .
$$

Mivel $\mathcal{K}_{\boldsymbol{\lambda}}^{*}$ egy konvex kúp, ebből következik, hogy azonos tartóhalmazú nemnegatív körpolinomok összege is nemnegatív körpolinom. Egy p polinom nemnegatív körpolinomok összegére bontásának feladata tehát ekvivalens azzal, hogy a $p$ polinom együtthatóvektorát felírjuk különböző $\boldsymbol{\lambda}$ vektorokhoz tartozó $\mathcal{K}_{\boldsymbol{\lambda}}^{*}$ kúpokba tartozó vektorok összegeként. Ez egy konvex kúp feletti lineáris optimalizálási feladat. Ilyen (szemidefinit programozásnál általánosabb) kúpfeltételeket tartalmazó feladatokat, a szemidefinit programozáshoz hasonlóan, belsőpontos módszerekkel oldhatunk meg hatékonyan, legalábbis amíg a kúpfeltételek száma nem túl nagy.

E cikk írásakor a leghatékonyabb szoftver a $\mathcal{K}_{\boldsymbol{\lambda}}$ hatványkúp és duális kúpja feletti optimalizálásra a MOSEK; az ebben implementált algoritmus részletei nem publikusak. Egy nyílt forráskódú szoftver általános kúpprogramozási feladatok megoldására az alfonso Matlab csomag [37]. 
A hatékony kúpprogramozási algoritmusok önmagukban még nem elégségesek egy SONC felbontás hatékony kiszámítására, mert a szükséges kúpfeltételek száma megegyezik a különböző tartóhalmazok számával. Wang közelmúltbeli eredménye, hogy minden SONC polinom $p$ felírható olyan körpolinomok összegeként, amelyek tartóhalmaza $p$ tartóhalmazának részhalmaza [56]. Ezzel a SONC tulajdonság ellenőrzéséhez megoldandó optimalizálási feladat kúpfeltételeinek számára véges (bár továbbra is exponenciális méretü) korlát adható. Egy közelmúltbeli eredmény, hogy a tartóhalmaz minimálisan affin összefüggő részhalmazainak kombinatorikus struktúráját felhasználva a SONC felbontást oszlopgenerálás segítségével gyorsan, a kúpfeltételek felsorolása nélkül, megtalálhatjuk [35].

\section{Diszkusszió}

Nem kerülhetjük meg a két bemutatott relaxáció összehasonlítását. A súlyozott számtani és mértani közép közötti egyenlőtlenség (és számos még általánosabb egyenlőtlenség) bizonyítható négyzetösszeggé alakítással [15], ebből a bizonyításból az következik, hogy SONC polinomok kellöen magas fokú hatványai négyzetösszeggé alakíthatók. Azonban, általános esetben, az SOS és SONC kúpok egyike sem tartalmazza a másikat: a Motzkin-polinom egy olyan nemnegatív körpolinom, ami nem alakítható négyzetösszeggé, míg az $\mathbb{R} \ni x \mapsto(1-x)^{4}$ polinom egy teljes négyzet, ám nem írható fel nemnegatív körpolinomok összegeként. Ebből adódóan, ha a (3) feladatban a nemnegatív kúpok halmazát e két kúp valamelyikével helyettesítjük, a priori nem világos, melyik esetben kapunk erősebb korlátot.

A két módszer futásidejét Seidler és DeWolff hasonlította össze nagy számú (mesterséges) feladaton [45]. A szemidefinit kúpnál egyszerűbb kúpokkal reprezentálhatóság, az elméleti eredményekkel összhangban, a gyakorlatban is azt eredményezi, hogy a SONC relaxációkkal nagyságrendekkel gyorsabban kaphatunk (nem feltétlenül éles) alsó korlátot egy polinomra, mint SOS relaxációkkal. Ugyanakkor az SOS polinomokra épülő hierarchiáknak (illetve Putinar Positivstellensatzának) nincsen ismert SONC analogonja, és az SOS relaxációkkal kapott korlátok többnyire erősebbek mint a SONC relaxációkkal kapható korlátok. Továbbá, mint említtettük, az SOS relaxációkat szemidefinit programozásnál hatékonyabb algoritmusokkal is megoldhatjuk [36].

Természetesen semmilyen elvi akadálya nincsen a két módszer összekapcsolásának: egy polinom nemnegativitásának elégséges feltétele, ha felbontható teljes négyzetek és nemnegatív körpolinomok összegére. Nem várható, hogy ez bármilyen lényeges elméleti előnnyel jár, de a fentiek következményeként az ilyen felbontás kiszámítása a négyzetösszeggé alakítással azonos nagyságrendű futásidőben megoldható, és a módszer örökli az SOS relaxáció összes elméleti tulajdonságát (Positivstellensatzok, stb.) 


\section{Köszönetnyilvánítás}

A szerző kutatását a National Science Foundation DMS-1719828 és DMS1847865 pályázata támogatta. ${ }^{2}$ A szerzö köszönetet mond Tóth Jánosnak a kézirat átolvasásáért és a hasznos kritikai megjegyzésekért, valamint Bozóki Sándornak a [15] hivatkozásért.

\section{References}

[1] A.A. Ahmadi And A. Majumdar: DSOS and SDSOS optimization: LP and SOCP-based alternatives to sum of squares optimization, In 48th Annual Conference on Information Sciences and Systems (CISS), IEEE, pp. 1-5, (2014). DOI: 10.1109/CISS.2014.6814141

[2] A.A. Ahmadi And A. Majumdar: Some applications of polynomial optimization in operations research and real-time decision making, Optimization Letters, Vol. 10, pp. 709-729 (2016). DOI: 10.1007/s11590-015-0894-3

[3] E. ARTiN: Über die Zerlegung definiter Funcktionen in Quadrate, Abhandlungen aus dem Mathematischen Seminar der Universität Hamburg, Vol. 5, pp. 100-115 (1927). DOI: 10.1007/BF02952513

[4] E.M. Aylward, S.M. Itani, ANd P.A. Parrilo: Explicit SOS decompositions of univariate polynomial matrices and the Kalman-Yakubovich-Popov lemma, In 46th IEEE Conference on Decision and Control, Dec, pp. 5660-5665 (2007). DOI: 10.1109/CDC.2007.4435026

[5] C. Bachoc and F. Vallentin: New upper bounds for kissing numbers from semidefinite programming, Journal of the American Mathematical Society, Vol. 21, pp. 909-924 (2008). DOI: 10.1090/S0894-0347-07-00589-9

[6] B. Ballinger, G. Blekherman, H. Cohn, N. Giansiracusa, E. Kelly, and A. SchürMANN: Experimental study of energy-minimizing point configurations on spheres, Experimental Mathematics, Vol. 18, pp. 257-283 (2009). DOI: 10.1080/10586458.2009.10129052

[7] G. Blekherman, P. A. Parrilo, and R. R. Thomas, Semidefinite Optimization and Convex Algebraic Geometry, SIAM, (2013).

[8] B. BorChers: CSDP, a C library for semidefinite programming, Optimization Methods \& Software, Vol. 11 No. 2, pp. 613-623 (1999). DOI: 10.1080/10556789908805765

[9] B. Boros: Existence of positive steady states for weakly reversible mass-action systems, SIAM Journal on Mathematical Analysis, Vol. 51, pp. 435-449 (2019). DOI: 10.1137/17M115534X

[10] E. Boros and P. L. Hammer: Pseudo-Boolean optimization, Discrete Applied Mathematics, Vol. 123, pp. 155-225 (2002). DOI: 10.1016/S0166-218X(01)00341-9

[11] E. De KLERK: The complexity of optimizing over a simplex, hypercube or sphere: a short survey, Central European Journal of Operations Research, Vol. 16, pp. 111-125 (2008). DOI: $10.1007 /$ s10100-007-0052-9

\footnotetext{
${ }^{2}$ This material is based upon work supported by the National Science Foundation under Grant No. DMS-1719828 and DMS-1847865.
} 
[12] E. De Klerk AND M. LAUREnT: Error bounds for some semidefinite programming approaches to polynomial minimization on the hypercube, SIAM Journal on Optimization, Vol. 20, pp. 3104-3120 (2010). DOI: 10.1137/100790835

[13] E. De Klerk, M. Laurent, and P.A. Parrilo: A PTAS for the minimization of polynomials of fixed degree over the simplex, Theoretical Computer Science, Vol. 361, pp. 210-225 (2006). DOI: $10.1016 /$ j.tcs.2006.05.011

[14] P.J.C. Dickinson And L. GiJBen: On the computational complexity of membership problems for the completely positive cone and its dual, Computational Optimization and its Applications, Vol. 57, pp. 403-415 (2014). DOI: 10.1007/s10589-013-9594-z

[15] P.E. Frenkel And P. Horváth: Minkowski's polynomial inequality and sums of squares, Central European Journal of Mathematics, Vol. 12, pp. 510-516 (2014).

DOI: $10.2478 / \mathrm{s} 11533-013-0346-1$

[16] D. Goluskin And G. FAntuzzi: Bounds on mean energy in the Kuramoto-Sivashinsky equation computed using semidefinite programming, Nonlinearity, Vol. 32, 1705 (2019). DOI: $10.1088 / 1361-6544 / \mathrm{ab018b}$

[17] M. Grötschel, L. Lovász, And A. Schrijver: Geometric Algorithms and Combinatorial Optimization, Springer Science \& Business Media, Vol. 2, (2012).

[18] D. Handelman: Representing polynomials by positive linear functions on compact convex polyhedra, Pacific Journal of Mathematics, Vol. 132, pp. 35-62 (1988). DOI: 10.2140/pjm.1988.132.35

[19] G.H. Hardy, J. E. Littlewood, and G.Pólya: Inequalities, Cambridge University Press, (1934).

[20] D. HilberT: Über die Darstellung definiter Formen als Summe von Formenquadraten, Mathematische Annalen, Vol. 32, pp. 342-350 (1888). DOI: 10.1007/BF01443605

[21] D. HilBerT: Mathematische probleme, Nachrichten von der Gesellschaft der Wissenschaften zu Göttingen, pp. 253-297 (1900). Illetve Archiv der Mathematik und Physik, Vol. 3, pp. 44-63 és pp. 213-237 (1901). Angol fordítása: Bulletin of the AMS, Vol. 8, pp. 437-479 (1902).

[22] S. Illman AND T. DE WolfF: Amoebas, nonnegative polynomials and sums of squares supported on circuits, Research in the Mathematical Sciences, Vol. 3, p. 9 (2016). DOI: $10.1186 /$ s40687-016-0052-2

[23] T. ILLÉS: Lineáris optimalizálás elmélete és belsőpontos algoritmusai, Eötvös Loránd Tudományegyetem, (2014). Egyetemi jegyzet. ELTE Operations Research Report 2014-04. http://web.cs.elte.hu/opres/orr/download/IT-LP-belsopontos-jegyzet-20140824.pdf

[24] Z. Jarvis-Wloszek, R. Feeley, W. Tan, K. Sun, And A. Packard: Some controls applications of sum of squares programming, in 42nd IEEE Conference on Decision and Control (CDC), vol. 5, IEEE, Dec, pp. 4676-4681 (2003). DOI: 10.1109/CDC.2003.1272309

[25] C. Josz: Counterexample to global convergence of DSOS and SDSOS hierarchies, arXiv preprint (2017). https://arxiv.org/abs/1707.02964

[26] J.B. LASSERRE: Global optimization with polynomials and the problem of moments, SIAM Journal on Optimization, Vol. 11, pp. 796-817 (2001). DOI: 10.1137/S1052623400366802 
[27] M. Laurent: Sums of squares, moment matrices, and optimization over polynomials, In Emerging Applications of Algebraic Geometry, M. Putinar and S. Sullivant, szerk., Vol. 149 of IMA Volumes in Mathematics and its Applications, Springer, pp. 157-270 2008. DOI: 10.1007/978-0-387-09686-5_7

[28] H. Lombardi, D. Perrucci, and M.-F. Roy: An elementary recursive bound for effective Positivstellensatz and Hilbert 17-th problem, arXiv preprint (2014). https://arxiv.org/abs/1404.2338

[29] M. Marshall: Positive Polynomials and Sums of Squares, AMS, (2008).

[30] K. MurTy And S. KABADI: Some NP-complete problems in quadratic and nonlinear programming, Mathematical Programming, Vol. 39, pp. 117-129 (1987). DOI: $10.1007 / \mathrm{BF} 02592948$

[31] Y. Nesterov: Squared functional systems and optimization problems, In High Performance Optimization, H. Frenk, K. Roos, T. Terlaky, and S. Zhang, szerk., Vol. 33 of Applied Optimization, Kluwer Academic Publishers, Dordrecht, The Netherlands, pp. 405-440 (2000).

[32] J. Nie and M. Schweighofer: On the complexity of Putinar's Positivstellensatz, Journal of Complexity, Vol. 23, pp. 135-150 (2007). DOI: 10.1016/j.jco.2006.07.002

[33] D. PAPP: Optimal designs for rational function regression, Journal of the American Statistical Association, Vol. 107, pp. 400-411 (2012). DOI: 10.1080/01621459.2012.656035

[34] D. PAPP: Semi-infinite programming using high-degree polynomial interpolants and semidefinite programming, SIAM Journal on Optimizaton, Vol. 27, pp. 1858-1879 (2017). DOI: $10.1137 / 15 \mathrm{M} 1053578$

[35] D. PAPP: Duality of sum of nonnegative circuit polynomials and optimal SONC bounds, arXiv preprint (2019). https://arxiv.org/abs/1912.04718

[36] D. PAPP AND S. YILDIZ: Sum-of-squares optimization without semidefinite programming, SIAM Journal on Optimizaton, Vol. 29, pp. 822-851 (2019). DOI: 10.1137/17M1160124

[37] D. PAPP AND S. YILDIZ: alfonso: Matlab package for nonsymmetric conic optimization, INFORMS Journal on Computing, (2021). Elfogadva.

Preprint: https://arxiv.org/abs/2101.04274,

Szoftver: https://github.com/dpapp-github/alfonso

[38] P.A. Parrilo: Structured Semidefinite Programs and Semialgebraic Geometry Methods in Robustness and Optimization, PhD disszertáció, California Institute of Technology, Pasadena, CA, May (2000).

[39] G. Pólya And G. Szegö: Problems and Theorems in Analysis, Springer, New York, NY, Vol. 2, (1976).

[40] M. Putinar: Positive polynomials on compact semi-algebraic sets, Indiana University Mathematics Journal, Vol. 42, pp. 969-984 (1993).

http://www. iumj . indiana. edu/IUMJ/FTDLOAD/1993/42/42045/pdf

[41] J. Renegar: A Mathematical View of Interior-Point Methods in Convex Optimization, No. 03 in MPS-SIAM Series on Optimization, MPS-SIAM, Philadelphia, PA (2001).

[42] C. Roos, T. Terlaky, and J.-P. Vial: Theory and Algorithms for Linear Optimization: An Interior Point Approach, Wiley, (1997). 
[43] K. Schmüdgen: The K-moment problem for compact semi-algebraic sets, Mathematische Annalen, Vol. 289, pp. 203-206 (1991). DOI: 10.1007/BF01446568

[44] M. Schweighofer: On the complexity of Schmüdgen's Positivstellensatz, Journal of Complexity, Vol. 20, pp. 529-543 (2004). DOI: 10.1016/j.jco.2004.01.005

[45] H. Seidler And T. DE WolfF: An experimental comparison of SONC and SOS certificates for unconstrained optimization, arXiv preprint (2018).

https://arxiv.org/abs/1808.08431

[46] N.Z. SHor: An approach to obtaining global extremums in polynomial mathematical programming problems, Cybernetics, Vol. 23, pp. 695-700 (1987). DOI: 10.1007/BF01074929

[47] G. Stengle: Complexity estimates for the Schmüdgen Positivstellensatz, Journal of Complexity, Vol. 12, pp. 167-174 (1996). DOI: 10.1006/jcom.1996.0011

[48] J.F. Sturm: Using SeDuMi 1.02, a Matlab toolbox for optimization over symmetric cones, Optimization Methods and Software, Vol. 11-12, pp. 625-653 (1999). DOI: 10.1080/10556789908805766. Lásd: http://sedumi.ie.lehigh.edu/

[49] G. Szederkényi, A. Magyar, and K. M. Hangos: Analysis and Control of Polynomial Dynamic Models with Biological Applications, Academic Press, London, UK, (2018).

[50] T. Terlaky: An easy way to teach interior-point methods, European Journal of Operational Research, Vol. 130, pp. 1-19 (2001). DOI: 10.1016/S0377-2217(00)00094-1

[51] K.C. Toh, M. J. TOdD, AND R. H. TÜTÜNCÜ: SDPT3 - a Matlab software package for semidefinite programming, version 1.3, Optimization Methods and Software, Vol. 11-12, pp. 545-581 (1999). DOI: 10.1080/10556789908805762

[52] J. Tóth, A. L. Nagy, And D. Papp: Reaction Kinetics: Exercises, Programs and Theorems, Springer-Verlag, New York, (2018).

[53] M. UJVÁRI: Szemidefinit programozás alkalmazásai a kombinatorikus optimalizálásban, Eötvös Loránd Tudományegyetem, (2001).

[54] L. Vandenberghe and S. P. Boyd: Semidefinite programming, SIAM Review, Vol. 38, pp. 49-95 (1996). DOI: $10.1137 / 1038003$

[55] C. Vinzant: What is ... a spectrahedron?, Notices of the American Mathematical Society, Vol. 61, pp. 492-494 (2014). https://www.ams.org/notices/201405/rnoti-p492.pdf

[56] J. WANG: Nonnegative polynomials and circuit polynomials, arXiv preprint arXiv:1804.09455 (2019).

[57] H. Wolkowicz, R. Saigal, and L. Vandenberghe, szerk.: Handbook of Semidefinite Programming: Theory, Algorithms, and Applications, Kluwer, Norwell, MA (2000). 


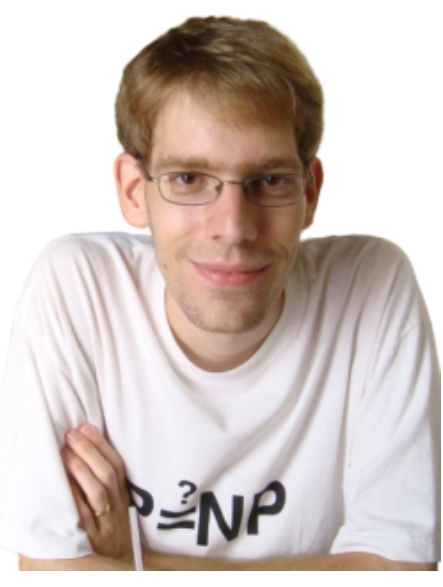

\section{PAPP DÁVID}

North Carolina State University

Department of Mathematics

Raleigh, NC 27695, USA

dpapp@ncsu.edu
Papp Dávid a North Carolina State University matematika tanszékének egyetemi docense. A Budapesti Müszaki Egyetemen folytatott müszaki informatikus tanulmányait követően a Rutgers University-n szerzett operációkutatás PhD fokozatot. 2011-2012 között a Northwestern University kutatója, 2013-2014 között a Massachusetts General Hospital munkatársa volt. Az amerikai National Science Foundation CAREER-díjas kutatója (2019). Kutatási területei a nemlineáris optimalizálás elmélete, valamint orvosi és statisztikai alkalmazásai.

\section{POLYNOMIAL OPTIMIZATION PROBLEMS AND THEIR RELAXATIONS}

\section{DÁVID PAPP}

Computing the extreme values of a polynomial over a closed semialgebraic set is a difficult problem with numerous applications both within and outside of the mathematical sciences. This paper gives a brief overview of the algebraic background of this area and some of the practical numerical methods applied in polynomial optimization. While polynomial optimization is NP-hard, several tractable convex relaxations of it have been proposed in the literature. We review two of them: sum-of-squares (SOS) relaxations, based on the Positivstellensatzes of Schmüdgen, Putinar, and others, and sum-of-nonnegative-circuit-polynomials (SONC) relaxations, motivated by the AM/GM inequality. After motivating and defining the sequences of these two types of relaxations, we outline how they can be efficiently solved using interior-point methods of semidefinite and non-symmetric cone programming.

Keywords: polynomial optimization, semidefinite programming, sums-of-squares, circuit polynomials.

Mathematics Subject Classification (2000): 90C22, 14Q20, 90C25, 13P15 